\title{
Influence of total length, sex and seasonal variations on hema- tological parameters in Cyprinus carpio (Linnaeus, 1758) (Pisces Cyprinidae) in Lake Tonga (Algeria)
}

\author{
Belhocine Karim*, Gasmi Yousria \& Khati Wyllia \\ Biodiversity and Pollution of Ecosystems Laboratory, Chadli Bendjedid University, El-Tarf, 36000 Algeria \\ Faculty of Natural and Life Sciences, Department of Marine Sciences. University El-Tarf, 36000 Algeria \\ *Corresponding author, e-mail: khati-hm@hotmail.com
}

ABSTRACT

\begin{abstract}
Hematological parameters are used as an essential tool to assess the health status of fish. This study aims to provide a background on hematology in Lake Tonga's Cyprinus carpio (Linnaeus, 1758) (Pisces Cyprinidae) and to demonstrate the impact of seasonal variations, sex and size on hematology. The study was conducted throughout 2018 and involved 120 individuals sampled monthly and randomly. The specimens were weighed and measured. Blood samples were collected to determine hematocrit (Ht), hemoglobin ( $\mathrm{Hb})$, red (GR) and white (GB) blood cell count (Lym, Mon, Gra) and erythrocyte constants: mean blood cell volume (VGM), mean blood cell content (TGM), mean corpuscular hemoglobin concentration $(\mathrm{CCMH})$. The results revealed that the majority of the parameters studied did not show significant differences in size classes, and the statistical comparison between the two sexes revealed significant differences in the values of GR, GB, Mon, Mon, Gra, Ht, $\mathrm{Hb}$, TGM and CCMH. On the other hand, all the parameters studied varied significantly over the seasons.
\end{abstract}

KEY WORDS

Cyprinus carpio; hematological parameters; Lake Tonga; sex; size.

Received 28.10.2019; accepted 17.12.2019; published online 30.12.2019

\section{INTRODUCTION}

Aquaculture in Algeria has become an area of increasing interest to the government and private sector producers, especially breeding activities and the introduction of new fish species.

The common carp Cyprinus carpio (Linnaeus, 1758 ) is a freshwater fish that is common worldwide (Welcomme, 1998). This global distribution of carp is linked to the many introductions around the world to promote aquaculture and sport fishing (Hoffmann, 1995; Copp et al., 2005; Balon, 2006). Fish are closely associated with their environment; physical and chemical changes in the environment are rapid and uncontrollable and can result in measurable physiological changes in fish (Fazio et al., 2013).

Hematological indices are important parameters for assessing the physiological state of fish and for defining the influence of different environmental factors, pollution or stress on their health (Romestand et al., 1983; Adams et al., 1993; Chen et al., 1995; Houston, 1997). Their changes depend on species, age, sex, sexual maturity cycle and health status (Sniezsko, 1960; Summerfeld, 1967; Blaxhall, 1972; Wedemeyer et al., 1983; Golovina \& Trombicky, 1989; Zhiteneva et al., 1989; Bielek \& Strauss, 1993; Golovina, 1996; Luskova, 1997; Vosyliene, 1999; Hrubec et al., 2001). 
Other factors that can significantly affect hematological parameters in teleosts include reproductive cycle, diet, temperature, $\mathrm{pH}$ and photoperiod (Sandnes et al., 1988; Kavadias et al., 1996; Svoboda et al., 2001; Guijarro et al., 2003; Kavadias et al., 2003; Bayir, 2005), or stress, pollution, parasitism, size, seasonal variations (Clarks et al., 1979; Barham et al., 1980; Ranzani-Paiva et al., 2004; Camargo et al., 2005; Santos et al., 2009; Onyia et al., 2013; De Souza Neves et al., 2014; Brum et al., 2014; Figueiredo et al., 2014; Fallah et al., 2014).

The aim of this study is to obtain basic information on the haematology of $C$. carpio from Lake Tonga, which is of interest in improving diagnostic and prognostic arguments by regularly monitoring samples from a fish or aquaculture population in order to achieve better control of farming conditions.

\section{MATERIAL AND METHODS}

\section{Study area}

Lake Tonga is located in the El-Kala National Park in the extreme north-east of Algeria $\left(36^{\circ} 53^{\prime} \mathrm{N}\right.$ and $08^{\circ} 31^{\prime} \mathrm{E}$ ). It occupies a vast coastal depression of 2600 hectares with a length of $7.5 \mathrm{~km}$ and width of $4 \mathrm{~km}$ (Fig. 1); it has been classified as a World Heritage Site and a RAMSAR site of international importance since 1983. This endorheic freshwater lake is currently the result of various works carried out over the past century and has become a marsh pond, communicating with the sea through an artificial channel, the Messida (Gehu et al., 1993).

The Lake Tonga catchment area, with a water volume of about $28,000,000 \mathrm{~m}^{3}$, which is significantly higher during periods of high water, includes two major rivers that flow all year round (Oued El Hout, $14 \mathrm{~km}$ long, and Oued El Eurg, $10 \mathrm{~km}$ long) and an outlet, which is Oued Messida (Bentouili, 2007).

The study region is subject to a Mediterranean climate characterized by two different seasons: a humid season, marked by heavy rainfall and low temperatures from October to May, and another dry and hot season with high temperatures reaching their maximum in August (Labar, 2004; Mebarki, 2010).

\section{Sampling}

120 specimens of common carp, C. carpio were regularly caught and sampled randomly and monthly from January to December 2017 using eel traps. The total length (Lt, $\mathrm{cm})$ of each fish was measured.

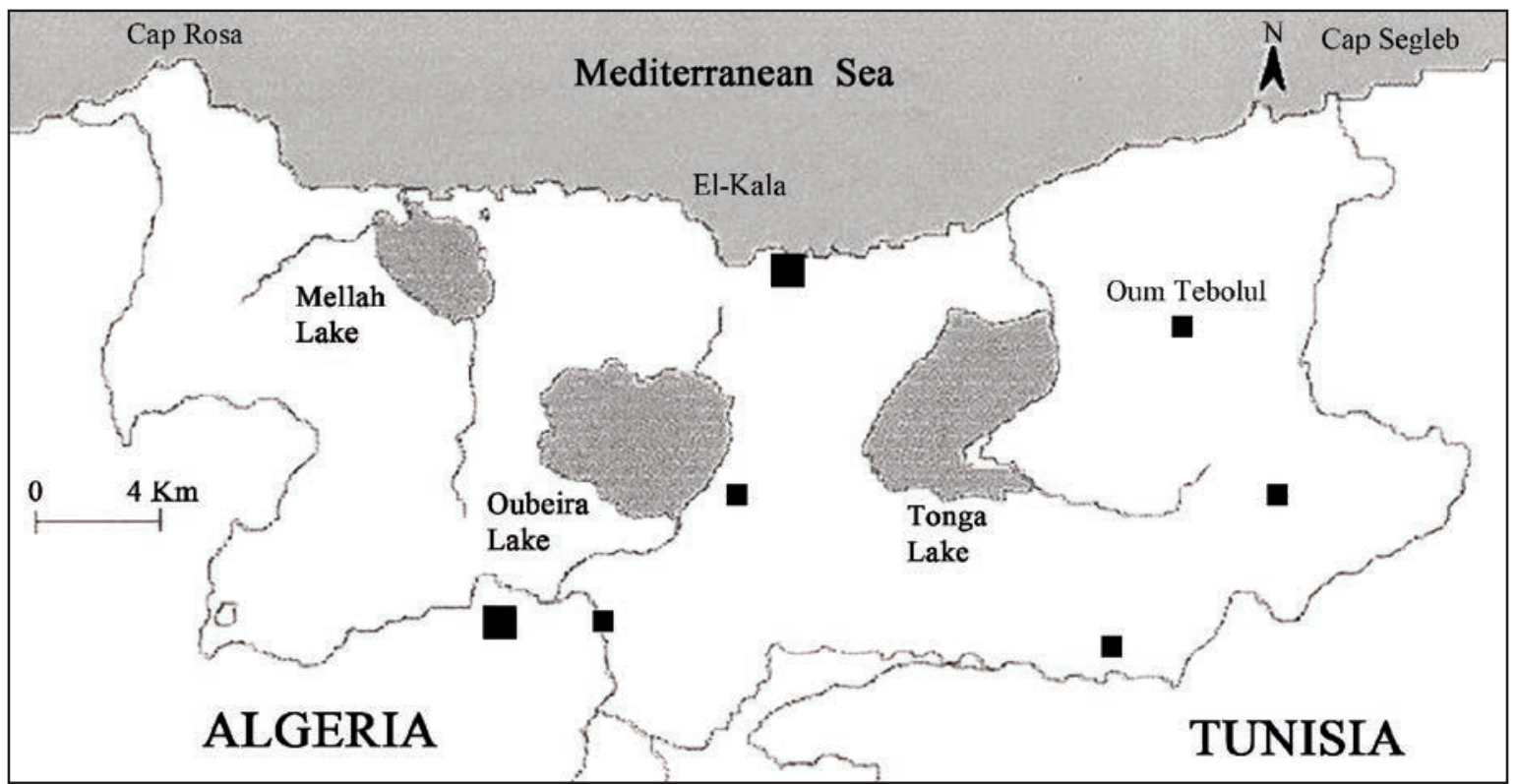

Figure 1. Geographical location of El-Kala National Park (Benyacoub, 1996). 
Blood samples were collected immediately on site as soon as the fish were caught by puncture of the caudal vein using a syringe containing a $10 \%$ anticoagulant -EDTA.

\section{Hematological parameters determinations}

Hematological parameters were measured by the following traditional analytical techniques: a $540 \mathrm{~nm}$ absorbance spectrophotometer using the hemoglobin cyanide procedure for hemoglobin $(\mathrm{Hb})$, by centrifugation of hematocrit capillaries for hematocrit $(\mathrm{Ht})$ and by counting red cells (GR) and white cells (GB) on Thomas cells after dilution in Rees solution (1 g bright cresyl blue, $31.3 \mathrm{~g}$ sodium citrate, $10 \mathrm{ml}$ formol $37 \%$ and $1000 \mathrm{ml}$ distilled water).

Leukocyte count was performed using stained blood smears with Giemsa / May-Grunwald stain solution (Rosenfeld, 1947); the smears were then examined under an optical microscope (Olympus, Tokyo, Japan) using an immersion oil at a magnification of x100 to obtain the percentage of lymphocytes (Lym), monocytes (Mon) and granulocytes (Gra).

The erythrocyte constants were calculated according to the Wintrobe method (1934) as follows: GMV: mean globular volume (in $\mathrm{fl})=\mathrm{Ht}$ (in $1 / 1) / \mathrm{Nb}$ red cells (Tera-/l); GMT: mean globular content (in pg) $=\mathrm{Hb}$ (g/l)/Nb red cells (Tera-/l); CCMH: mean corpuscular hemoglobin concentration (in $\mathrm{g} /)=\mathrm{Hb}(\mathrm{g} / \mathrm{l}) / \mathrm{Ht}(\mathrm{l} / \mathrm{l})$.

The data were analyzed by ANOVA for analysis of variance with a significance of $5 \%$, and the means were compared by the Tukey test. The differences were considered significant at $p \leq 0.05$. Minitab statistical software (version 17) was used for all statistical analyses.

\section{RESULTS}

The total length of the 120 fish studied ranged from $21.4 \mathrm{~cm}$ to $61.4 \mathrm{~cm}$ (average $33.73 \pm 8.82$ ). Using Sturges' law, the specimens examined were grouped into 8 size classes of $5 \mathrm{~cm}$ in amplitude. The statistical comparison between different size classes revealed that the majority of the parameters studied did not show significant differences (Table 1).

The largest fish $(56-61 \mathrm{~cm})$ had the highest levels of GR, GB, Hb, Mon and CCMH.

Table 2 shows the results of the hematological indices for males and females. The statistical comparison between the two sexes revealed significant differences in the values of GR, GB, Mon, Mon, $\mathrm{Gra}, \mathrm{Ht}, \mathrm{Hb}, \mathrm{TGM}$ and CCMH. Higher amounts of $\mathrm{Ht}, \mathrm{Hb}$ and Lym were reported in males, while higher values of GR, GB, VGM, TGM, CCMH, Mon and Gra were reported in females. Analysis of the hematological parameters studied for C. carpio caught in Lake Tonga waters showed that all values varied significantly over the seasons. In contrast, $\mathrm{Hb}$ was the only non-significant parameter (Table 3).

The highest values of Mon, Gra, TGM and $\mathrm{CCMH}$ were recorded in the spring. In summer, the number of Lym, GR and $\mathrm{Hb}$ reach their maximum. In contrast, the highest numbers of GB and GMVs were observed in winter. Hematocrit is the only parameter that reached its peak in autumn.

\section{DISCUSSION}

Hematology can be used to study fish respon-

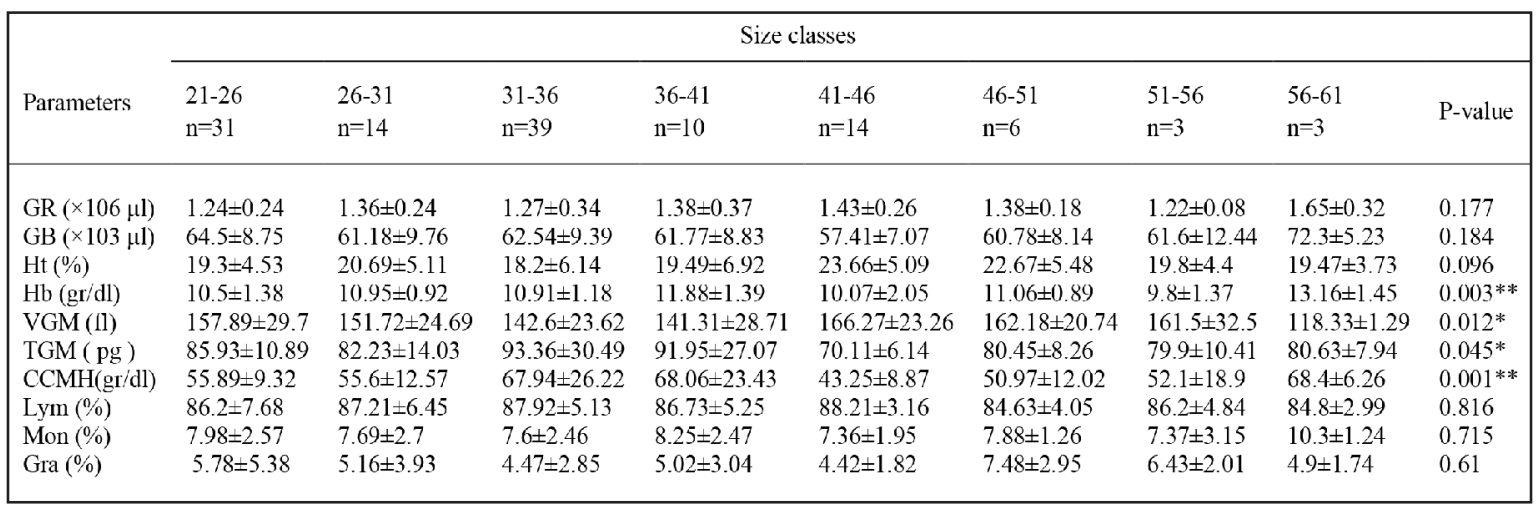

Table 1. Comparison of hematological indices in Cyprinus carpio from Lake Tonga as a function of total length. $\mathrm{P}>0.05=$ Not Significant; $\mathrm{P}<0.05=$ Significant $(*) ; \mathrm{P}<0.01=$ Highly Significant $(* *)$. 


\begin{tabular}{|llll|}
\hline Parameters & \multicolumn{1}{c}{ Males n=50 } & Females n=70 & P. Value \\
\hline GR $(\times 106 \mu \mathrm{l})$ & $1.51 \pm 0.23$ & $1.81 \pm 0.26$ & $<0.001^{* * *}$ \\
$\mathrm{~GB}(\times 103 \mu \mathrm{l})$ & $57.98 \pm 6.93$ & $65.48 \pm 9.14$ & $<0.001^{* *}$ \\
$\mathrm{Ht}(\%)$ & $22.54 \pm 5.24$ & $17.87 \pm 5.06$ & $<0.001^{* *}$ \\
$\mathrm{Hb}(\mathrm{gr} / \mathrm{dl})$ & $11.13 \pm 1.75$ & $10.61 \pm 1.14$ & 0.054 \\
$\mathrm{VGM}(\mathrm{fl})$ & $150.56 \pm 29.55$ & $151.51 \pm 25.31$ & 0.85 \\
$\mathrm{TGM}(\mathrm{pg})$ & $74.21 \pm 9.01$ & $94.44 \pm 24.04$ & $<0.001^{* *}$ \\
$\mathrm{CCMH}(\mathrm{gr} / \mathrm{dl})$ & $51.84 \pm 14.15$ & $64.6 \pm 21.66$ & $<0.001^{* * *}$ \\
Lym $(\%)$ & $90.29 \pm 2.93$ & $84.27 \pm 6.18$ & $<0.001^{* *}$ \\
Mon $(\%)$ & $6.45 \pm 1.59$ & $8.78 \pm 2.42$ & $<0.001^{* * *}$ \\
Gra $(\%)$ & $3.26 \pm 1.79$ & $6.48 \pm 4.13$ & $<0.001^{* *}$ \\
\hline
\end{tabular}

Table 2. Comparison of hematological indices between males and females of Cyprinus carpio from Lake Tonga. $\mathrm{P}$ $>0.05=$ Not Significant; $\mathrm{P}<0.05=$ Significant $(*) ; \mathrm{P}<0.01$ $=$ Highly Significant $(* *)$.

siveness to different environmental conditions, which allows a better understanding of their physiology and health status and to develop the most optimal environments for aquaculture. Hematology can also be used in the diagnosis and treatment of diseases (Ranzani-Paiva et al., 2013).

In recent years, the study of fish haematological parameters has received increasing attention and has become a key issue for aquaculture. However, several factors are likely to modify the blood parameters of a fish (size, sex and seasonal fluctuations, etc.).

The findings presented in this study on the effect of seasonal variations, sex and size on hematological parameters in C. carpio from Lake Tonga showed that many hematological indices differed significantly with respect to sex and seasonal variations, but were not significant with respect to total length.

The results obtained after the total length effect study show that the rates of GR, GB, Hb, Mon and $\mathrm{CCMH}$ were higher in the longest fish. This is consistent with the results of Jawad et al. (2004). The authors found that GR and $\mathrm{Hb}$ values increased with increasing fish size. Poston (1966) and Anthony et al. (2010) also observed that the number of GR and $\mathrm{Hb}$ tends to increase with the length and age of the fish. As a result, rapid increases in body weight, as well as an increase in blood volume, are accompanied by adequate erythropoiesis (Svetina et al., 2002).

In addition, it may also be the result of changes in plasma or erythrocyte volume (Sandstrom, 1989). However, Chaudhuri et al. (1986) suggested that this relationship may be due to the higher metabolic rate in large fish compared to smaller.
Furthermore, Ranzani-Paiva (1995), Svetina et al. (2002) and Baghizadeh \& Khara (2015) suggested that the CCMH increased with the age of the C. carpio carp, which would be due to adaptation strategies adopted at different life stages.

However, no significant change in hematocrit level relative to total length was observed, despite the general trend observed in the relationship between blood hematocrit and body length of $C$. carpio: the longer the fish, the higher the hematocrit, as reported by Murachi (1959), Svetina et al. (2002) and Hrubec et al. (2001) for mature hybrid tilapias, Oreochromis spp. and Orun \& Erdeml (2002), in the case of the long spine scraper, Capoeta trutta (Heckel, 1843).

GBs are defense cells of the body. According to Douglass and Jane (2010), their levels influence immune responses and the animal's ability to fight infection. White blood cell counts are frequently used as an indicator of health status for fish, as for other vertebrates. These cells are key components of the innate immune defense and participate in the regulation of immunological function in the body (Ballarin et al., 2004). The GB values do not show any significant difference between the size classes. On the other hand, differences in hematological parameters by sex of fish have already been proven (Gabriel et al., 2004; Akinrotimi et al., 2007).

Many studies have shown that males show the highest values in almost all hematological indices; these high values are attributed to greater physiological activity in males (Cech \& Wohlschlag, 1981; Orun et al., 2003). Moreover, higher metabolic activity in males may lead to differences in blood cell components (Collazos et al., 1998). Parma \& Croux (1994) demonstrated that the variation in hematological indices between the two sexes could be due to differential oxygen demand.

The findings of Fourie \& Hattingh (1976) and Baghizadeh \& Khara (2015) for C. carpio and those of Jawad et al. (2004) for Tenualosa ilisha F. Hamilton, 1822 are in agreement with the results of this study, which showed that $\mathrm{Hb}, \mathrm{Ht}$ and Lym were higher in males than in females.

Whereas, the results of Orun et al. (2003) as well as Orun \& Erdeml (2002) for cyprinids were quite the opposite of the results of this study, showing that the number of red and white blood cells in males was lower than in females. Differences in leukocyte count could be attributed in particular to 


\begin{tabular}{|llllll|}
\hline Parameters & $\begin{array}{l}\text { Winter } \\
\mathrm{n}=30\end{array}$ & $\begin{array}{l}\text { Spring } \\
\mathrm{n}=30\end{array}$ & $\begin{array}{l}\text { Summer } \\
\mathrm{n}=30\end{array}$ & $\begin{array}{l}\text { Autumn } \\
\mathrm{n}=30\end{array}$ & P. Value \\
\hline $\mathrm{RG}(\times 106 \mu \mathrm{l})$ & $1.21 \pm 0.18$ & $1.09 \pm 0.33$ & $1.53 \pm 0.20$ & $1.43 \pm 0.23$ & $<0.001^{* *}$ \\
$\mathrm{~GB}(\times 103 \mu \mathrm{l})$ & $67.54 \pm 7.31$ & $66.86 \pm 9.7$ & $54.07 \pm 4.97$ & $60.94 \pm 6.51$ & $<0.001^{* *}$ \\
$\mathrm{Ht}(\%)$ & $19.8 \pm 3.64$ & $15.46 \pm 4.96$ & $21.95 \pm 6.12$ & $22.05 \pm 4.96$ & $<0.001^{* *}$ \\
$\mathrm{Hb}(\mathrm{gr} / \mathrm{dl})$ & $10.71 \pm 1.08$ & $11.08 \pm 1.25$ & $10.63 \pm 1.76$ & $10.89 \pm 1.61$ & 0.641 \\
VGM (fl) & $163.53 \pm 18.8$ & $142.72 \pm 23.19$ & $143.13 \pm 31.27$ & $155.08 \pm 28.5$ & $0.005^{* *}$ \\
TGM ( pg) & $89.27 \pm 9.83$ & $108.72 \pm 27.86$ & $69.31 \pm 6.53$ & $76.74 \pm 9.33$ & $<0.001^{* *}$ \\
CCMH & $55.4 \pm 9.25$ & $8.54 \pm 24.33$ & $51.58 \pm 15.38$ & $51.61 \pm 13.49$ & $<0.001^{* *}$ \\
$(\mathrm{gr} / \mathrm{dl})$ & $84.86 \pm 5.7$ & $83.05 \pm 5.72$ & $91.98 \pm 2.26$ & $88.28 \pm 4.23$ & $<0.001^{* *}$ \\
Lym $(\%)$ & $8.42 \pm 2.06$ & $9.78 \pm 2.09$ & $5.81 \pm 1.36$ & $7.22 \pm 2.09$ & $<0.001^{* *}$ \\
Mon (\%) & $6.71 \pm 4.16$ & $7.15 \pm 3.91$ & $2.20 \pm 1.06$ & $4.48 \pm 2.58$ & $<0.001^{* *}$ \\
Gran $(\%)$ & & & & & \\
\hline
\end{tabular}

Table 3. Seasonal comparison of hematological indices of Cyprinus carpio from Lake Tonga. $\left(\mathrm{P}>0.05=\right.$ Not Significant $\mathrm{P}<0.05=$ Significant $(*) ; \mathrm{P}<0.01=$ Highly Significant $\left.\left({ }^{* *}\right).\right)$

stress, age, maturity, gender, pathogens (biotic factors) and/or water temperature, $\mathrm{pH}$, dissolved oxygen content (abiotic factors) (Pavlidis et al., 2007). As a result, all these environmental variations make interpretation difficult.

The majority of hematological parameters were higher in months of high temperature to meet the considerable energy demand of the fish. They had significantly lower values in months of low temperature due to the body's high metabolic rate due to high body temperature and reproductive activities. These results were not in agreement with the work of Joshi (1989), Orun et al. (2003), Adebayo et al. (2007), Khadjeh et al. (2010) and Kohanestani et al. (2013). As a result, it is recommended that further hematological studies be conducted on the same fish species to obtain further results.

\section{CONCLUSIONS}

This study aimed to provide information on the hematology of C. carpio from Lake Tonga (El KalaAlgeria) based on seasonal changes, sex and size. The study was conducted throughout 2018 and involved 120 individuals sampled monthly and randomly.

Seasonal fluctuations were found to have a significant effect on all parameters studied, with the exception of $\mathrm{Hb}$. Sex had a significant effect on the values of GR, GB, Mon, Gra, Ht, Hb, TGM and $\mathrm{CCMH}$. On the other hand, significant differences in the comparison of total length were observed only in the values $\mathrm{Hb}$, GMV, GMT and CCMH. As a result, these results will serve as preliminary data for further studies.

Therefore, it is recommended that further and more detailed research be carried out to determine the effects of the three factors mentioned on hematological parameters in fish, due to the increasing importance given to fish farming and the increased awareness of pollution of aquatic ecosystems.

\section{REFERENCES}

Adams S.M., Brown A.M. \&. Goede R.W., 1993. A quantitative health assessment index for rapid Evaluation of fish condition in the field. Transactions of the American Fisheries Society, 122: 63-73. https:// doi.org/10.1577/1548-8659(1993)122<0063:AQH $\mathrm{AIF}>2.3 . \mathrm{CO} ; 2$

Adebayo O.T., Fagbenro O.A., Ajayi C.B. \& Popoola O.M., 2007. Normal haematological profile of Parachanna obscura as a dignostic tool in aquaculture. International Journal of Zoological Research, 3: 193-199. https://doi.org/10.3923/ijzr.2007.193.199

Akinrotimi O.A., Gabriel U.U., Anyanw P.E. \& Anyanwu A.O., 2007. Influence of sex, acclimation methods and period on haematology of Sarotherodon melanotheron (Cichilidae). Research Journal of Biological Sciences, 2: 348-352.

Baghizadeh E. \& Khara H., 2015. Variability in hematology and plasma indices of common carp Cyprinus carpio, associated with age, sex and hormonal treat- 
ment. Iranian Journal of Fisheries Sciences. 14: 99111.

Ballarin L., Dall'Oro M., Bertotto D., Libertini A., Francescon A. \& Barbaro A., 2004. Haematological parameters in Umbrina cirrosa (Teleostei, Sciaenidae): a comparison between diploid and triploid specimens. Comparative Biochemistry and Physiology. Part A, Molecular \& Integrative Physiology, 138: 45-51. Pmid: 15165570. https://doi.org/10. 1016/j.cbpb.2004.02.019.

Balon E.K., 2006. The oldest domesticated fishes, and the consequences of an epigenetic dichotomy in fish culture. Aqua, Journal of Ichthyology Aquatic Biology, 11: 47-86.

Barham W.T., Smith G.L. \& Schnoobe H.J., 1980. The effect of bacterial infection on erythrocyte fragility and sedimentation rate of rainbow trout, Salmo gairdneri (Richardson). Journal of Fish Biology, 16: 177-180.

Bayir A., 2005. The investigation of seasonal changes in antioxidant enzyme activities, serum lipids, lipoproteins and hematological parameters of siraz fish (Capoetacapoetaumbla) living in Hns Stream (Murat Basin). M.Sc. Thesis Dissertation, Atatürk University.

Bentouili M.Y., 2007. Inventaire et Qualité des Eaux des Sources du Parc National d'El-Kala (N-Est, algérien), Ingénieur d'Etat, Universite Badji Mokhtar-Annaba, Département de Géologie, 134 pp.

Benyacoub S., 1996. Diagnose écologique de l'avifaune du Parc National d'Elkala. Composition - Statut - Répartition. Etude individuelle. $\mathrm{N}^{\circ}$ EI10. Projet Banque Mondiale, $67 \mathrm{pp}$.

Bielek E. \& Strauss B., 1993. Ultrastructure of the granulocyte of the South American lungfish, Lepidosiren paradoxa: morphogenesis and comparison to other leucocytes. Journal of Morphology, 218: 29-41.

Blaxhall P.C., 1972. The haematological assessment of the health of freshwater fish. Journal of Fish Biology, 4: 593-604.

Brum A., Dotta G., Roumbedakis K., Gonçalves E.L., Garcia L.P., Garcia P., Scussel V.M. \& Martins M.L., 2014. Hematological and histopathological changes in silver catfish Rhamdia quelen (Siluriformes) exposed to clomazone herbicide in the Madre River, Santa Catarina State, Southern Brazil. Journal of Environmental Science and Health, Part B: Pesticides, Food Contaminants, and Agricultural Wastes, 49: 169-175. https://doi.org/10.1080/03601234.2014. 858007

Camargo J.A., Alonso A. \& Salamanca A., 2005. Nitrate toxicity to aquatic animals: a review with new data for freshwater invertebrates. Chemosphere, 58: 1255 1267. https://doi.org/10.1016/j.chemosphere.2004. 10.044

Cech J.J. \& Wohlschlag D.E., 1982. Seasonal patterns of respiration, gill ventilation and hematological char- acteristic in the striped mullet, Mugil cephalus L. Bulletin of Marine Science, 32: 130-138

Chaudhuri S.H., Pandit T. \& Benerjee S., 1986. Size and sex related variations of some blood parameters of Sarotheriodon mossambica. Environment and Ecology, 1: 61-63.

Chen G.R., Sun L-T., Lee Y-H. \& Chang C-F., 1996. Characteristics of blood in common carp, Cyprinus carpio, exposed to low temperatures. Journal of Applied Aquaculture, 5: 21-31.

Clark S., Whitemore D.H. Jr. \& McMahon R.F., 1979. Consideration of blood parameters of largemouth bass, Micropterus salmoides. Journal of Fish Biology, 14, 147-154. https://doi.org/10.1111/j.1095-8649. 1979.tb03504.x

Collazos M.E., Ortega E., Barriga C. \& Rodriguez A.B., 1998. Seasonal variation in haematological parameters in male and female Tinca tinca. Molecular and Cellular Biochemistry, 183: 165-168.

Copp G.H., Bianco P.G., Bogutskaya N.G., Erős T., Falka I., Ferreira M.T., Fox M.G., Freyhof J., Gozlan R.E., Grabowska J., Kováč V., Moreno-Amich R., Naseka A.M., Peňáz M., Povž M., Przybylski M., Robillard M., Russell I.C., Stakènas S., Šumer S., Vila-Gispert A. \& Wiesner C., 2005. To be, or not to be, a non-native freshwater fish? Journal of Applied Ichthyology 21: 242-262. https://doi.org/10.1111/j.1439-0426. 2005.00690.x

De Souza Neves M., Barbas L.A.L. \& Fujimoto R.Y., 2014. Haematology and recovery response in jacundà, Crenicichla saxatilis (Linnaeus, 1758) after short-term handling stress. Journal of Applied Ichthyology, 30: 42 - 47. https://doi.org/10.1111/jai.12298

Fallah F.J., Khara H., Roohi J.D. \& Boorani M.S., 2014. Hematological parameters of pike Esox lucius in relation to different ages and seasons. Comparative Clinical Pathology, 23: 949-953. https://doi.org/10. 1007/s00580-013-1719-3

Fazio F., Marafioti S., Torre A., Sanfilippo M., Panzera M. \& Faggio C., 2013. Haematological and serum protein profiles of Mugil cephalus: effect of two different habitats. Ichthyological Research, 60: 36-42. https://doi.org/10.1007/s10228-012-0303-1.

Figueredo A.B., Tancredo K.R., de Olibeira Hashimoto G.S., Roumbedakis K., da Costa Marchoiri N. \& Martins M.L., 2014. Hematological and parasitological assessment of silver catfish Rhamdia quelen farmed in Southern Brazil. Revista brasileira de parasitologia veterinaria, 23: 1-7. https://doi.org/10. 1590/S1984-29612014028

Gabriel U.U., Ezeri G.N.O. \& Opabunmi O.O., 2004. Influence of sex, source, health status and acclimation on the haematology of Clarias gariepinus (Burch, 11822). African Journal of Biotechnology, 3: 463467. 
Gehu J.M., Kaabeche M. \& Ghazouli R., 1993. Phytosociologie et typologie des habitats des rives des lacs de la région d'El Kala (Algérie). Colloques Phytosociologiques XXII, Syntazonomie typologique des habitats: $297-329$.

Golovina N.A., 1996. Morphofunctional characteristics of the blood of fish as objects of aquiculture. Doctoral Thesis. Moscow, $53 \mathrm{pp}$.

Golovina N.A. \& Trombicky I.D., 1989. Haematology of Pond Fish. Kishinev, Shtiinca, 158 pp.

Guijarro A.I., Lopez-Patiço M.A., Pinillos M.L., Isorna E., De Pedro N., Alonso-Gomez A.L., Alonso-Bedate M. \& Delgado M.J., 2003. Seasonal changes in hematology and metabolic resources in the tench. Journal of Fish Biology, 62: 803-815. https://doi.org/ 10.1046/j.1095-8649.2003.00066.x

Hardig J. \& Hoglund L.B., 1983. On accuracy in estimating fish blood variables. Comparative Biochemistry and Physiology, 1: 35-40.

Hoffmann R.C., 1995. Environmental change and the culture of common carp in medieval Europe. Guelph Ichthyology Reviews, 3: 57-85.

Houston A.H., 1997. Review: Are the classical hematological variables acceptable indicators of fish Health? Transactions of the American Fisheries Society, 126: 879-894. https://doi.org/10.1577/15488659(1997) $126<0879:$ RATCHV $>2.3 . C O ; 2$

Hrubec T.C., Smith S.A. \& Robertson J.L., 2001. Agerelated ichanges in haematology and plasma chemistry values of hybrid striped bass (Morone chrysops $\mathrm{x}$ Morone saxatilis). Veterinary Clinical Pathology, 30: 8-15. https://doi.org/10.1111/j.1939-165X.2001. tb00249.x

Ikechukwu O. A. \& Obinnaya C.L., 2010. Haematological profile of the African lungfish, Protopterus annectens (Owen) of Anambra River, Nigeria. Journal of American Science, 6: 123-130.

Jawad L.A., Al-Mukhtar M.A. \& Ahmed H.K., 2004. The relationship between haematocrit and some biological parameters of the Indian shad, Tenualosa ilisha (Family Clupeidae). Animal Biodiversity and Conservation, 27: 478-483.

Jawad L.A., Al-Mukhtar M.A. \& Ahmed H.K., 2004. The relationship between haematocrit and some biological parameters of the Indian shad, Tenualosa ilisha (Family Clupeidae). Animal Biodiversity and Conservation, 27: 47-52.

Joshi P.C., 1989. Seasonal changes in the blood parameters of a hillstream teleost, Channa gochua. Comparative Physiology Ecology 14: 71-73.

Kavadias S., Castritsi-Catharios J. \& Dessypris A., 2003. Annual cycles of growth rate, feeding rate, food conversion, plasma glucose and plasma lipids in a population of European sea bass (Dicentrarchus labrax L.) farmed in floating marine cages. Journal of Applied Ichthyology, 19: 29-34.
Khadjeh G.H., Mesbah M., Nikmehr S. \& Sabzevarizadeh M., 2010. Effect of sex on the haematological parameters of reared shirboat fish (Barbus grypus). Iranian Journal of Veterinary Research, 65: 217-224.

Kohanestani Z.M., Hajimoradloo A., Ghorbani R., Yulghi S., Hoseini A. \& Molaee M., 2013. Seasonal variations in hematological parameters of Alburnoides eichwaldii in Zaringol Stream-Golestan Province, Iran. World Journa of Fish and Marine Sciences, 5: 121-126. https://doi.org/10.5829/idosi.wjfms.2013. 05.02.71110

Labar S., 2004. Contribution à l'identification des aires inondables et qualité physico-chimiques des eaux stagnantes temporaires dans la vallée de la Mafragh "Extrême Nord Est Algérien”, Magister thesis, Dept. Of geology, Badji Mokhtar Annaba University, 155 pp.

Le F., Fourie R. \& Hattingh J., 1976. A seasonal study of the haematology of carp, (Cyprinus carpio) from a locality in the Transvaal, South Africa. Zoologica Africana, 11: 75-80. https://doi.org/10.1080/0044 5096.1976.11447516

Lusková V., 1997. Annual cycles and normal values of haematological parameters in fishes. Acta Scientiarum Naturalium, 31: 70.

Mebarki M., 2010. Apport des cours d'eau et cartographie du bilan hydrologique: cas des bassins de l'Algérie orientale, Science et changements planétaire Sécheresse, 21: 301-308. https://doi.org/10.1684/sec. 2010.0265.

Murachi S., 1959. Haemoglobin contents, erythrocytes sedimentation rate and haematocrit of the blood in the young of the carp (Cyprinus carpio). Journal Faculty of Fisheries and Animal Husbandry, 2: 241-247.

Onyia L.U., Michael K.G. \& Ekoto B., 2013. Haematological profile, blood group and genotype of Heterobranchus bidorsalis. Net Journal of Agricultural Science, 1: 69-72.

Örün I. \& Erdeml A.U., 2002. A study on blood parameters of Capoeta trutta (Heckel, 1843). Journal of Biological Science, 2: 508-511. https://doi.org/10.3923/ jbs.2002.508.511

Örün I., Dörücü M. \& Yazlak H., 2003. Haematological parameters of three cyprinid fish species from Karakaya Dam Lake, Turkey. Online Journal of Biological Sciences, 3: 320-328.

Parma de Croux M.J., 1994. Some haematological parameters in Prochilodus lineatus. Revue d'hydrobiologie Tropicale, 27: 113-119.

Pavlidis M., Futter W.C., Kathario P. \& Divanach P., 2007. Blood cells of six Mediterranean mariculture fish species. Journal of Applied Ichthyology, 23: 7073.https://doi.org/10.1111/j.1439-0426.2006.00771. x

Poston H.A., 1966. Effect of sex and reproductive stage on haemoglobin level in brown trout. Fisheries Research Bulletin, 29: 28-29. 
Ranzani-Paiva M.J.T., 1995. Características hematológicas de tainha Mugil platanus Günther, 1880 (Osteichthyes, Mugilidae) da região estuarino-lagunar de Cananéia- SP (Lat. $25^{\circ} 00^{\prime}$ - Long. $47^{\circ} 55^{\prime}$ 'W). Boletim do Instituto de Pesca, 22: 1-22.

Ranzani-Paiva M.J.T., Ishikawa C.M., Ccuzza das Eiras A. \& Da Silveira V.R., 2004. Effects of an experimental challenge with Mycobacterium marinum on the blood parameters Of Nile tilapia, Orechromis niloticus (Linnaeus, 1757). Brazilian Archives of Biology and Technology, 47: 945-953. http://dx.doi. org/10.1590/S1516-89132004000600014

Ranzani-Paiva M. J. T., Pádua S. B., Tavares-Dias M. \& Egami M. I., 2013. Métodos para análise hematológica em peixes. EDUEM, Brazil, 140 pp. https://doi. org/10.7476/9788576286530

Romestand B., Halsband E., Bragoni G., Knezevic B., Maric D. \& Prochnow F., 1983. Étude hématologique comparée des constantes érythrocytaires de quelques poissons marins et d'eaux douces. Revue de Travaux de l'Institut des Pêches maritimes, 46: 147-156.

Rosenfeld G., 1947. Corante pancrômico para hematologia e citologia clínica. Nova combinação dos componentes do maygrünwald e do Giemsa num só corante de emprego rápido. Memórias do Instituto Butantan, 20: 329-334.

Sandnes K., Lie Ø. \& Waagbø R., 1988. Normal ranges of some blood chemistry parameters in adult farmed Atlantic salmon, Salmo salar. Journal of Fish Biology, 32: 129-136. https://doi.org/10.1111/j.10958649.1988.tb05341.x

Sandström O., 1989. Seasonal variations in some blood parameters in perch, Perca fluviatilis L. Journal of Applied Ichthyology, 5: 80-84. https://doi.org/10. 1111/j.14390426.1989.tb00477.x

Santos A.A., Egami M.I., Ranzani-Paiva M.J.T. \& Juliano Y., 2009. Hematological parameters and phagocytic activity in fat snook (Centropomus parallelus): seasonal variation, sex and gonadal maturation.
Aquaculture, 296: 359-366. https://doi.org/10.1016/ j.aquaculture.2009.08.023

Snieszko S., 1960. Microhaematocrit as a tool in fisheries management. U.S. Fish and Wildlife Service, Special Scientific Report-Fisheries, 314, Washington, 15 pp.

Trojan S., 2003. Medical physiology. Grada publishing, Prague, $771 \mathrm{pp}$.

Summerfelt R.C., Lewis W.M. \& Ulrich M.G., 1967. Measurement of some hematological characteristics of the goldfish. The Progressive Fish-Culturist, 29: 13-20.

Svetina A., Matašin Ž., Tofant A., Vucemilo M. \& Fijan N., 2002. Haematology and some blood chemical parameters of young carp till the age of three years. Acta Veterinaria Hungarica, 50: 459-467. https://doi. org/10.1556/AVet.50.2002.4.8

Svoboda M., Kouril J., Hamakova J., Kalab P., Savina L., Svobodova Z. \& Vykusova B., 2001. Biochemical profile of blood plasma of tench (Tinca tinca L.) During pre- and post-spawning period. Acta Veterinary Brno, 70: 259-268. https://doi.org/10.2754/avb200 170030259

Vosyliene M.Z., 1999. The effect of heavy metals on haematological indices of fish (survey). Acta Zoologica Lituanica, 9: 76-82. https://doi.org/10.1080/ 13921657.1999.10512290

Wedemeyer G.A., Gould R.W. \& Yasutake W.T., 1983. Some potentials and limits of the leucocrit test as a fish health assessment method. Journal of Fish Biology, 23: 711-716. https://doi.org/10.1111/j.10958649.1983.tb02948.x

Welcomme R.L., 1998. International Introductions of Inland Aquatic Species, Food \& Agriculture, Organization of the United Nation, Rome, $318 \mathrm{pp}$.

Wintrobe M.M., 1934. Variations on the size and hemoglobin content of erythrocytes in the blood various vertebrates. Folia Haematologie, 5: 32-49.

Zhiteneva L., Poltavceva T.G. \& Rudnickaja O.A., 1989. Atlas of normal and pathological cells in the blood of fish. Rostov-on-Don, $112 \mathrm{pp}$. 